\title{
PENGARUH PENGGUNAAN TEKNOLOGI DI MASA PANDEMI COVID-19 TERHADAP HASIL BELAJAR PADA MATA PELAJARAN BIOLOGI DI MAN 2 JEMBER
}

\author{
Aisya Nur Afifa ${ }^{1}$, Sarifatul Ula ${ }^{1}$, Siti A. Azizah ${ }^{1}$ \\ ${ }^{1}$ Institut Agama Islam Negeri Jember, Jl. Mataram No.1 Mangli, Jember 68136, \\ Jawa Timur, Indonesia \\ E-mail: aisyanurafifa615@gmail.com
}

DOI: 10.35719/alveoli.v2i1.35

\begin{abstract}
Technology and information are important instruments that must be present in online learning during a pandemic that can determine the effectiveness of biology learning which has an impact on student learning outcomes. The effectiveness of online learning during the pandemic in MAN 2 Jember is known to be $65.8 \%$ of students' opinions about the effectiveness of learning biology are not effective, $68.4 \%$ of students do not agree with the implementation of learning biology using technology online, and there are 7 students who experience an increase in presentation and 19 decreased perfomance in achievement in student biology learning in the mist of COVID-19 pandemic. This research uses descriptive research with a survey approach. The research objects are students and teachers. The instrument used was a questionnaire regarding the process of learning outcomes in biology with the technical data analysis used in this study was to count the number of respondents answers to each question. The purpose of this study was to determine how the influence of technology used on student learning outcomes in MAN 2 Jember in the midst of the COVID-19 pandemic. Therefore, with the existence of online biology learning processes, there are still deficiencies in understanding biological material, and deficiencies in the application of information technology. So that with this research, teachers and students are expected to be able to better master the material and technology so that they can adapt well to the learning process during the COVID19 pandemic.
\end{abstract}

Keyword: COVID-19, the influence of technology, learning outcomes

\begin{abstract}
Abstrak: Teknologi dan informasi merupakan instrumen penting yang harus ada dalam pembelajaran daring di masa pandemi yang dapat menentukan keefektifan pembelajaran biologi yang berdampak pada hasil belajar siswa. Efektivitas Pembelajaran daring di masa Pandemi di MAN 2 Jember diketahui 65,8\% pendapat dari siswa efektivitas pembelajaran biologi tidak efektif, 68,4\% siswa tidak setuju dengan pelaksanaan pembelajaran biologi menggunakan teknologi secara daring, dan terdapat 7 siswa mengalami kenaikan dalam presentasi dan 19 penurunan prestasi dalam hasil belajar biologi siswa di tengah pandemi COVID-19. Penelitian ini menggunakan penelitian deksriptif dengan pendekatan survey. Objek penelitian adalah siswa dan guru. Instrumen yang digunakan adalah kuesioner mengenai proses hasil belajar terhadap mata pelajaran biologi dengan teknis analisis data yang digunakan dalam penelitian ini adalah menghitung jumlah jawaban responden dari setiap pertanyaan. Tujuan dari penelitian ini adalah untuk mengetahui bagaimana pengaruh penggunaan teknologi terhadap hasil belajar siswa di MAN 2 Jember di tengah pandemi COVID-19. Maka dari itu dengan adanya proses pembelajaran biologi secara daring masih terdapat kekurangan dalam pemahaman materi biologi, dan kekurangan pada pengaplikasian teknologi informasi. Sehingga dengan adanya penelitian ini guru dan siswa diharapkan mampu untuk lebih menguasai materi dan teknologi agar dapat beradaptasi dengan baik pada proses pembelajaran di masa pandemi COVID-19.
\end{abstract}

Kata Kunci: COVID-19, pengaruh teknologi, hasil belajar

Pandemi COVID-19 yang terjadi saat ini telah membawa perubahan besar bagi Indonesia juga di seluruh dunia. Virus ini menyebar dan menjadi penyebab angka kematian tertinggi saat ini. Hal ini tentulah membawa dampak besar bagi seluruh sektor kehidupan. Akibatnya 
banyak fasilitas pendidikan, pusat perbelanjaan dan lain sebagainya yang ditutup. Herliandy dalam Nova (2020) salah satu cara untuk memutus mata rantai penyebaran COVID-19 adalah dengan melakukan pembatasan interaksi masyarakat yang diterapkan dengan istilah physical distancing. Namun, kebijakan physical distancing tersebut dapat menghambat laju pertumbuhan dalam berbagai bidang kehidupan, baik pada bidang ekonomi, sosial, dan tentu saja pendidikan. Keputusan pemerintah untuk meliburkan para peserta didik, memindahkan proses belajar mengajar di sekolah menjadi di rumah dengan menerapkan kebijakan Work From Home (WFH) membuat resah banyak pihak (Mustakim, 2020).

Kebijakan-kebijakan yang dikeluarkan untuk membatasi penyebaran virus corona berdampak pada berbagai bidang di seluruh dunia terkhusus pada pendidikan Pembelajaran yang harusnya dilakukan dengan bertatap muka beralih menjadi pembelajaran online. Pembelajaran daring, online atau pembelajaran jarak jauh sendiri bertujuan untuk memenuhi standar pendidikan dengan pemanfaatan teknologi informasi dengan menggunakan perangkat komputer atau gadget yang saling terhubung antara siswa dan guru maupun antara mahasiswa dengan dosen sehingga melalui pemanfaatan teknologi tersebut KBM bisa tetap dilaksanakan dengan baik (Pakpahan, 2020 dalam Nova, 2020). Salah satu penyebab dari perubahan besar ini adalah dikarenakan pembelajaran online ini dilakukan secara tiba-tiba, hal ini berakibat besar pada kesiapan sekolah, guru dan siswa dalam melaksanakan pembelajaran yang belum memadai. Terlebih lagi akibat dari dampak pandemi COVID-19 yang melanda sehingga pembelajaran tidak berjalan maksimal karena harus tetap di rumah dan menerapkan physical distancing (Abidin, 2020 dalam Nova, 2020).

Pembelajaran daring atau online merupakan pembelajaran berdasarkan pada teknologi yang bahan belajarnya dikirim secara elektronik ke peserta didik dari jarak jauh menggunakan jaringan komputer. Menurut pemerintah, pembelajaran online dinilai merupakan cara yang paling efektif untuk melakukan pembelajaran di tengah pandemi seperti saat ini. Namun pembelajaran daring ini banyak dikeluhkan oleh siswa dan mahasiswa karena dirasa kurang efektif. Selama ini kurangnya penguasaan perangkat teknologi informasi dan komunikasi juga menjadi problem dalam pendidikan di Indonesia. Hal ini berpengaruh pada kemampuan siswa dalam mengakses berbagai informasi yang berakibat pada kemajuan dunia secara umum dan dunia pendidikan secara khusus (Nureza, 2020).

Dalam pelaksanaan pembelajaran daring memberikan tantangan tersendiri bagi pelaku pendidikan, seperti pendidik, peserta didik, institusi dan bahkan memberikan tantangan bagi masyarakat luas seperti para orang tua. Dalam pelaksanaannya pendidik harus mencari cara bagaimana agar tetap bisa menyampaikan materi pembelajaran dan dapat diterima dengan 
mudah oleh peserta didik. Begitu juga peserta didik yang dituntut agar bisa menyesuaikan diri dalam situasi dan kondisi seperti saat ini, salah satunya kesiapan mental (Abdul, 2020).

Era globalisasi saat ini, perkembangan teknologi informasi dan komunikasi yang semakin pesat dan telah merambah berbagai aspek kehidupan manusia, termasuk dalam dunia pendidikan di berbagai negara termasuk Indonesia. Bahkan adanya tekanan teknologi informasi dan komunikasi atau Information and Communication Technologies (ICT) yang sangat besar terhadap sistem pendidikan secara global karena teknologi yang berkembang menyediakan kesempatan yang sangat besar untuk mengembangkan manajemen pendidikan dan proses pembelajaran di perguruan tinggi (Wiliam, 2015)

Dalam melaksanakan pembelajaran daring tentu saja tidak dapat lepas dari penggunaan teknologi informasi dan komunikasi atau ICT. Teknologi informasi dapat mempermudah semua kebutuhan dalam menjalankan proses belajar mengajar dan hasil dari proses belajar tersebut. ICT adalah sistem pembelajaran berbasis multimedia (teknologi yang melibatkan teks, gambar, suara, dan video) mampu membuat penyajian suatu topik bahasan menjadi menarik, tidak monoton dan mudah untuk dicerna. Peran yang sangat penting dan strategis ini sebagai pusat belajar, pusat budaya, dan pusat peradaban menuntut lembaga-lembaga pendidikan untuk dapat mengembangkan aktivitas pembelajaran yang jelas dan daya jangkau yang luas. Namun perlu di ketahui bahwa ICT hanyalah sebagai alat bantu dalam proses pembelajaran (Adisel, 2020). Kemampuan dalam mengakses informasi dan komunikasi akan mempengaruhi kemampuan dan proses belajar siswa dalam memahami mata pelajaran, hal tersebut berhubungan dengan penelitian ini yang akan mengkaji tentang pembelajaran daring dalam mata pelajaran biologi.

Seiring dengan perkembangan zaman teknologi informasi dan komunikasi semakin berkembang, pada saat ini banyak platform yang dapat membantu pelaksanaan pembelajaran daring seperti Google Classroom, E-learning, Edmodo, Moodle, rumah belajar, dan platform dalam bentuk video konferens sudah semakin banyak antara lain seperti Google Meet, Zoom, dan Visco Webex. Adanya pandemi COVID-19 yang berpengaruh besar terhadap psikologi pembelajaran dan hasil belajar siswa yang menjadikan hal baru untuk lebih mengefektifkan proses belajar siswa agar menghasilkan hasil belajar yang maksimal. Berdasarkan uraian tersebut, penelitian ini akan membahas mengenai hasil belajar siswa saat memanfaatkan teknologi dalam pembelajaran serta pendidikan yang dihadapi selama masa pandemic COVID-19 saat ini.

Pada penelitian ini ditujukan bagi siswa siswi dan guru di lembaga pendidikan MAN 2 Jember yang dikhususkan pada mata pelajaran biologi untuk memberikan suatu tanggapan 
tentang pengaruh teknologi terhadap hasil belajar siswa di masa pandemi. Seiring dengan proses pembelajaran daring pastinya terdapat segi positif dan negatif dari penggunaan teknologi dalam melakukan kegiatan pembelajaran daring. Untuk mengetahui pengaruh teknologi terhadap hasil belajar pada mata pelajaran biologi, dilakukan penelitian yang mencakup keefektifan proses pembelajaran daring pada kegiatan pembelajaran biologi, pengaruh penggunaan teknologi informasi dan komunikasi pada kegiatan pembelajaran biologi, dan hasil belajar pada mata pelajaran biologi siswa melalui prestasi yang dapat menentukan keberhasilan dari pengaruh teknologi terhadap hasil belajar pada mata pelajaran biologi yang ada di lembaga pendidikan MAN 2 Jember.

\section{METODE}

Penelitian ini menggunakan penelitian deksriptif dengan pendekatan survey. Populasi dari penelitian ini terdapat dalam satu sekolah yang merupakan guru-guru biologi dengan jumlah 6 orang dan Siswa-siswi dari jurusan IPA yang terdiri dari angkatan kelas 10 dengan jumlah 160 siswa, kelas 11 berjumlah 162 siswa, dan kelas 12 berjumlah 170 siswa. Sehingga total keseluruhan adalah 498 responden. Sedangkan sampel dari penelitian ini sebanyak 41 orang yang bersedia mengisi google form. Objek penelitian adalah guru dan siswa. Instrumen yang digunakan adalah kuesioner mengenai proses hasil belajar terhadap mata pelajaran biologi dengan teknis analisis data yang digunakan dalam penelitian ini adalah menghitung jumlah jawaban responden dari setiap pertanyaan.

\section{HASIL}

Berikut merupakan hasil persentase siswa MAN 2 Jember terhadap mata pelajaran biologi dengan menggunakan teknologi sebagai sarana penunjang pembelajaran di masa pandemi COVID-19:

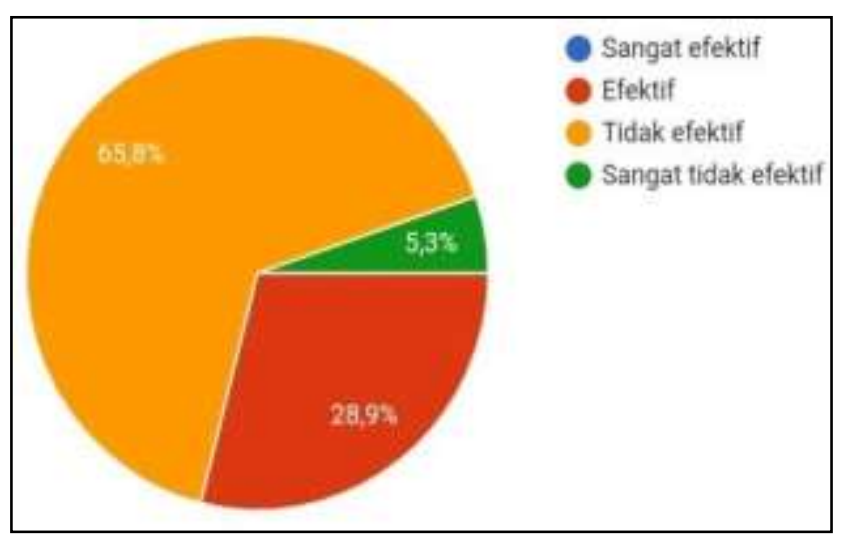

Gambar 1. Respon Siswa pada Keefektifan Kegiatan Pembelajaran Daring Mata Pelajaran Biologi 
Pada (Gambar 1) menunjukkan efektifitas pembelajaran daring di masa pandemi menurut siswa MAN 2 Jember. Dari data tersebut diketahui 28,9\% siswa menganggap pembelajaran daring di masa pandemi efektif dilakukan, 65,8\% siswa menganggap pembelajaran daring di masa pandemi tidak efektif dilakukan dan 5,3\% siswa menganggap pembelajaran daring di masa pandemi sangat tidak efektif dilakukan. Artinya kebanyakan siswa lebih cenderung menganggap bahwa pembelajaran daring di masa pandemi tidak efektif untuk dilakukan.

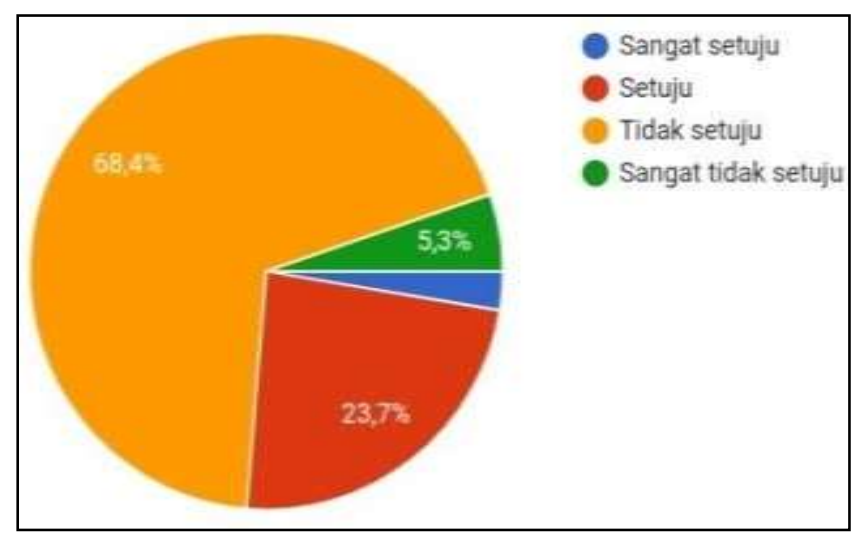

\section{Gambar 2. Respon Siswa pada Pelaksanaan Pembelajaran Mata Pelajaran Biologi Menggunakan Teknologi Secara Daring}

Pada (Gambar 3) menunjukkan pelaksanaan pembelajaran biologi dengan menggunakan teknologi secara daring menurut siswa MAN 2 Jember. Dari data tersebut diketahui $23,7 \%$ siswa setuju, $0 \%$ siswa sangat setuju, 5,3\% siswa sangat tidak setuju dan 68,4\% siswa tidak setuju. Berdasarkan data tersebut, kebanyakan siswa tidak setuju jika pelaksanaan pembelajaran biologi dilakukan secara daring.

Tabel 1. Respon Siswa Terhadap Hasil Belajar Materi Biologi dengan Menggunakan Teknologi di Masa Pandemi COVID-19

\begin{tabular}{cc}
\hline Tingkat Prestasi & Jumlah Siswa \\
\hline Naik & 7 \\
Standar & 12 \\
Menurun & 19 \\
\hline
\end{tabular}

Pada (Tabel 1) menunjukkan hasil belajar siswa pada materi biologi dengan menggunakan teknologi di masa pandemi menurut siswa MAN 2 Jember. Hasil belajar ini merupakan output yang diterima siswa selama menggunakan teknologi selama masa pandemi ini. Diketahui dari tabel tersebut sebanyak 7 siswa mengalami peningkatan hasil belajar, 12 siswa memiliki hasil belajar yang standar dan 19 siswa mengalami penurunan hasil belajar. 
Hal ini menunjukkan bahwa siswa masih kesulitan untuk memahami materi biologi dengan menggunakan teknologi pada masa pandemi.

\section{PEMBAHASAN}

Pada dasarnya pendidikan ini merupakan salah satu pondasi dari berkembangnya suatu negara yang menciptakan generasi-generasi yang beradab memiliki intelektual yang tinggi dan mampu membangun negara yang berkembang. Pendidikan merupakan kunci dalam kelengkapan tujuan hidup bangsa yang merdeka, pendidikan juga memberikan berbagai perubahan positif terhadap manusia. Pelaksanaan pendidikan di Indonesia belum bisa dikatakan tepat karena masih ada beberapa masalah pendidikan di Indonesia seperti adanya kalangan masyarakat yang masih belum memperoleh pendidikan yang layak kemudian disusul mewabahnya penyakit COVID-19. Oleh karena itu, di tengah mewabahnya virus COVID-19 ini pemerintah menghimbau untuk melakukan pembelajaran daring atau belajar dari rumah masing-masing untuk setiap lembaga pendidikan. Tanpa terkecuali MAN 2 Jember yang juga melakukan proses pembelajaran daring, salah satunya yakni pada mata pelajaran biologi. Dengan diadakannya pembelajaran daring tentunya paling utama yang dibutuuhkan yaitu penggunaan teknologi informasi dan komunikasi.

\section{Efektifitas Pembelajaran Daring}

Disaat kegiatan pembelajaran berlangsung perlu diperhatikan keefektifan dengan kata lain tingkat keberhasilan yang dicapai. Ciri-ciri keefektifan program pembelajaran adalah berhasil mengantarkan siswa mencapai tujuan-tujuan instruksional yang telah ditentukan, memberikan pengalaman belajar yang atraktif, melibatkan siswa secara aktif sehingga menunjang pencapaian tujuan instruksional dan memiliki sarana-sarana yang menunjang proses belajar mengajar (Rohmawati, 2015 dalam Hikmat, 2020). Bukan hanya hasil dari pembelajaran keefektifan pembelajaran dapat dilihat, namun proses belajar juga dapat dinilai sebagai tolak ukur untuk menilai keefektifan suatu pembelajaran.

Pada (Gambar 1) menunjukkan bahwa respon siswa MAN 2 Jember terhadap pembelajaran daring di masa pandemi berbeda antar siswa. Persentase terbanyak diperoleh pada pilihan tidak efektif dengan persentase $65,8 \%$. Kemudian disusul dengan pilihan efektif dengan persentase $28,9 \%$ dan terakhir pilihan sangat tidak efektif dengan presentase $5,3 \%$. Hal ini menunjukkan bahwa mayoritas siswa di MAN 2 Jember masih kesulitan dalam menerima materi ketika pembelajaran daring. Hal ini bisa terjadi karena beberapa macam faktor. Menurut Dilon dalam Andrianto (2019) berdasarkan studi yang dilakukan sebelumnya menunjukkan bahwa terdapat 3 hal yang dapat memberikan efek terkait pembelaja- 
ran secara daring: (1) teknologi, secara khusus pengaturan jaringan harus memungkinkan untuk terjadinya pertukaran sinkronisasi dan asinkronisasi; siswa harus memiliki akses yang mudah (misalnya melalui akses jarak jauh); dan jaringan seharusnya membutuhkan waktu minimal untuk pertukaran dokumen. (2) karakteristik pengajar, pengajar memainkan peran sentral dalam efektivitas pembelajaran secara daring, bukan sebuah teknologi yang penting tetapi penerapan instruksional teknologi dari pengajar yang menentukan efek pada pembelajaran, siswa yang hadir dalam kelas dengan instruktur yang memliki sifat positif terhadap pendistribusian suatu pembelajaran dan memahami akan sebuah teknologi akan cenderung menghasilkan suatu pembelajaran yang lebih positif. Dalam lingkungan belajar konvensional siswa cenderung terisolasi karena mereka tidak memiliki lingkungan khusus untuk berinteraksi dengan pengajar. (3) karakteristik siswa (Leidner, 1993 dalam Andrianto, 2019) mengungkapkan bahwa siswa yang tidak memiliki keterampilan dasar dan disiplin diri yang tinggi dapat melakukan pembelajaran yang lebih baik dengan metode yang disampaikan secara konvensional, sedangkan siswa yang cerdas serta memiliki disiplin serta kepercayaan diri yang tinggi akan mampu untuk melakukan pembelajaran dengan metode daring.

2. Pengaruh Teknologi Terhadap Pembelajaran Daring

Berdasarkan hasil dari (Gambar 2) menunjukkan pelaksanaan pembelajaran biologi dengan menggunakan teknologi secara daring menurut siswa MAN 2 Jember. Dari data tersebut diketahui $23,7 \%$ siswa setuju, $0 \%$ siswa sangat setuju, 5,3\% siswa sangat tidak setuju dan $68,4 \%$ siswa tidak setuju. Artinya kebanyakan siswa tidak setuju jika pelaksanaan pembelajaran biologi dilaksanakan menggunakan tekonologi atau secara daring. Hal ini dikarenakan sesuai respon dari angket yang telah diberikan terdapat beberapa hambatan yaitu hambatan pertama dari segi penggunaan teknologi informasi dan komunikasi (HP, laptop, dan notebook) adalah terdapat pada pengaplikasian media dari internet yang ditemukan ketidakseimbangan jaringan internet (sinyal). Jaringan tidak stabil juga merupakan hambatan dalam proses pembelajaran dengan sistem daring. Keberadaan fasilitas jaringan merupakan hal yang utama dalam pembelajaran sistem daring, karena berkaitan dengan kelancaran proses pembelajaran. Kedua, keberadaan responden yang jauh dari pusat kota ataupun jauh dari jangkauan jaringan provider tentunya tidak dapat melaksanakan proses pembelajaran dengan lancar (Dindin, 2020).

Hambatan kedua yaitu kurangnya pemahaman materi biologi yang dijelaskan melalui teknologi informasi dikarenakan materi biologi merupakan materi yang membutuhkan penjelasan langsung melalui tatap muka. Terutama pada siswa kelas XII yang terdapat 
materi dan sekaligus praktikum yang harus dilakukan. Perlu diketahui alasan kurang fahamnya memahami materi biologi menggunakan teknologi yaitu karena biologi merupakan ilmu pengetahuan alam yang sering mempelajari tentang organisme makhluk hidup. Memberikan pengetahuan kepada siswa akan kuasanya Tuhan sehingga dapat meningkatkan keimanan dan akhlaq siswa. Objek kajian biologi sangat luas dan mencakup semua makhluk hidup. Karenanya, dikenal berbagai cabang biologi yang mengkhususkan diri pada setiap kelompok organisme, seperti botani adalah cabang ilmu untuk mempelajari tumbuhan, zoologi adalah cabang ilmu untuk mempelajari hewan, mikrobiologi adalah cabang ilmu untuk mempelajari mikroorganisme, dan ekologi adalah cabang ilmu untuk mempelajari ekosistem. Berbagai aspek kehidupan dikupas tuntas melalui cabang biologi seperti ciri-ciri fisik dipelajari dalam anatomi (tumbuhan, hewan maupun manusia), sedang fungsinya dipelajari dalam fisiologi. Hubungan antar sesama makhluk dan dengan alam sekitar dapat dipelajari dalam ekologi, dan mekanisme pewarisan sifat dipelajari dalam genetika (Arfi, 2013). Oleh karena itu, untuk memahami nya masih kurang mudah jika dipahami melalui teknologi informasi dan komunikasi saja. Namun dengan kondisi mewabahnya COVID-19 maka penggunaan teknologi ini diharuskan untuk tujuan berlangsungnya kegiatan belajar materi biologi bagi siswa MAN 2 Jember.

3. Hasil Belajar Siswa

Berdasarkan hasil penelitian pada (Tabel 1) menunjukkan hasil belajar siswa pada materi biologi dengan menggunakan teknologi di masa pandemi menurut siswa MAN 2 Jember. Hasil belajar ini merupakan output yang diterima siswa selama menggunakan teknologi selama masa pandemi ini. Diketahui hasil belajar pada 7 siswa mengalami kenaikan, hasil belajar 12 siswa memberikan hasil standar (tidak naik dan tidak turun) dan hasil belajar pada 19 siswa mengalami penurunan. Hal ini menunjukkan bahwa siswa masih kesulitan untuk memahami materi biologi dengan menggunakan teknologi pada pembelajaran daring di masa pandemi COVID-19.

Penelitian ini mendapatkan hasil bahwa kenaikan hasil belajar 7 siswa rata-rata didasarkan pada penemuan model atau metode belajar yang baru digunakan. Sehingga mereka dapat mempelajari ilmu-ilmu baru tentang penggunaan beberapa teknologi yang sering dipergunakan dalam pembelajaran online, misalnya dalam penggunaan e-mail dan WPS untuk pengumpulan tugas. Dalam pembelajaran daring rata-rata siswa siswi MAN 2 Jember mengalami kenaikan prestasi dalam menggunakan teknologi. Mereka dapat menggunakan berbagai perangkat atau aplikasi sebagai penunjang pembelajaran, untuk mengetahui sumber-sumber pengetahuan, dan digunakan dalam penyampaian informasi 
materi pembelajaran. Peneliti juga mendapatkan hasil bahwa kenaikan hasil belajar tersebut dapat terjadi dikarenakan apabila siswa tersebut terus berusaha dari dirinya sendiri untuk giat belajar walaupun dalam situasi dan kondisi pandemi COVID-19. Sehingga dampak yang didapatkan oleh siswa tersebut adalah prestasi belajar yang stabil atau bahkan meningkat. Sesuai dengan penelitian terdahulu, yakni menurut penelitian Rusdiana dalam Novia, $d k k$ (2020) menunjukkan bahwa 47,19\% seseorang tertarik mengikuti pembelajaran daring $71 \%$ mengaku termotivasi dalam mengikuti pembelajaran daring tersebut. Motivasi dalam mengikuti pembelajaran daring $78,61 \%$ ditimbulkan oleh tampilan materi yang menarik, 87,6\% karena kesesuaian materi dengan tujuan pembelajaran, dan 76,4\% karena faktor efektifitas waktu belajar.

Menurut Novia, $d k k$ (2020) kelebihan pembelajaran secara daring memiliki kelebihan sebagai berikut :

1. Siswa dapat belajar (mereview) bahan ajar setiap saat dan dimana saja apabila diperlukan mengingat bahan ajar tersimpan di komputer.

2. Bila siswa memerlukan tambahan informasi yang berkaitan dengan bahan yang di- pelajarinya, ia dapat melakukan akses di internet.

3. Siswa dapat melakukan diskusi melalui internet yang dapat diikuti dengan jumlah peserta yang banyak.

4. Berubahnya peran siswa dari yang pasif menjadi aktif.

Hasil belajar siswa MAN 2 Jember terdapat 12 siswa yang hasil belajarnya hanya biasa saja (standar). Siswa-siswi tersebut dalam penelitian menyebutkan bahwa pembelajaran daring di MAN 2 Jember masih kurang efektif dan hasilnya tidak maksimal. Hal tersebut dapat terjadi jika penerapan proses ataupun metode dalam pembelajaran daring tidak dilakukan dengan baik dan tidak disesuaikan dengan masing-masing kemampuan siswa.

Menurut Novia, $d k k$ (2020) kelebihan pembelajaran secara daring memiliki kelebihan sebagai berikut :

1. Siswa dapat belajar (mereview) bahan ajar setiap saat dan dimana saja apabila diperlukan mengingat bahan ajar tersimpan di komputer.

2. Bila siswa memerlukan tambahan informasi yang berkaitan dengan bahan yang dipelajarinya, siswa dapat melakukan akses di internet.

3. Siswa dapat melakukan diskusi melalui internet yang dapat diikuti dengan jumlah peserta yang banyak.

4. Berubahnya peran siswa dari yang pasif menjadi aktif. 
Hasil penelitian menurut (Tabel 1) bahwa hasil belajar 19 siswa menurun. Faktorfaktor penurunan hasil belajar siswa MAN 2 Jember selama pembelajaran daring setelah dilakukan penelitian yakni pemahaman yang kurang terhadap materi yang disampaikan oleh guru, beberapa siswa juga sering terkendala sinyal, dan kebanyakan siswa mengalami kejenuhan dan merasa sepi dalam pembelajaran daring. Seperti yang diketahui bahwa pemaparan materi oleh guru kepada siswa sangat berkaitan erat dengan tingkat kebrhasilan prestasi siswa tersebut. Jika guru gagal dalam menyampaikan materi dengan baik kepada siswa maka dampak yang akan didapatkan adalah siswa akan mengalami penurunan dalam prestasi belajarnya, tidak hanya itu sekolah juga akan mendapatkan imbasnya jika siswasiswanya mengalami penurunan dalam prestasi belajarnya. Menurut pendapat Hamid dalam Novia, $d k k$ (2020), mengenai kelebihan pembelajaran daring dari segi waktu dan akses yang tidak terbatas. Sedangkan kekurangannya terletak pada kecepatan proses umpan balik, persiapan waktu pengajar lebih lama dan berpotensi menurunnya rasa nyaman, cemas, dan bingung. Penelitian tersebut menunjukkan bahwa siswa-siswi MAN 2 Jember mengalami rasa kejenuhan dalam pembelajaran daring. Hal ini dikarenakan kenyamanan dalam proses pembelajaran sangat mendukung dalam tingkat kerbehasilan prestasi belajar siswa selama masa pandemi COVID-19 berlangsung.

Selain pemahaman yang kurang akan materi yang didapatkan oleh siswa, kebanyakan siswa-siswi MAN 2 Jember mengeluh akan kendala sinyal saat proses pembelajaran daring berlangsung. Tidak dapat dipungkiri bahwa kemampuan siswa, kondisi ekonomi, dan tempat tinggal mereka adalah berbeda-beda. Mereka akan mendapatkan pembelajaran yang berlangsung baik dan lancar jika sinyal internet mereka juga mendukung. Berbanding terbalik jika kondisi sinyal internet di rumah mereka tidak mumpuni, maka hal tersebut akan sangat berdampak pada hasil belajar siswa tersebut. Sesuai dengan teori yang didapatkan bahwa kejenuhan juga dapat menjadi penghambat semangat siswasiswi MAN 2 Jember dalam pembelajaran daring. Kondisi yang mengharuskan mereka untuk selalu berada di rumah dan bosan akan pembelajaran online sangat berdampak akan keberhasilan belajar siswa tersebut. Mereka lebih kurang akan rasa semangat dalam belajar karena masih belum terbiasa dengan pembelajaran daring tersebut. Namun seiring mereka terbiasa mereka juga malah menjadi jenuh karena pembelajaran tidak berjalan sesuai dengan semestinya.

Menurut Hidayat dalam Pawicara dan Conilie (2020) kejenuhan dapat terjadi akibat dari adanya tuntutan bagi peserta didik untuk selalu mematuhi aturan tugas-tugas yang diembankan untuk peserta didik. Kejenuhan belajar juga terjadi karena kegiatan yang sela- 
lu sama yang dikerjakan oleh peserta didik disetiap harinya. Kejenuhan ini akan berdampak bagi peserta didik untuk keberlangsungan pendidikannya. Perilaku yang ditunjukkan seseorang yang mengalami kejenuhannya itu mudah cepat marah, mudah terluka, dan mudah frustasi.

Selain melakukan penelitian terhadap hasil belajar pada siswa, peneliti juga melakukan penelitian terhadap guru biologi di MAN 2 Jember. Hasil yang didapatkan guru tersebut tidak setuju dalam pemberian materi biologi secara mandiri melalui online ataupun E-learning. Di MAN 2 Jember juga memberikan kebebasan kepada guru untuk menjalankan tugasnya yaitu memberikan materi kepada siswa dengan menggunakan teknologi E-learning. Menurut hasil yang didapatkan peneliti, guru tersebut berpendapat bahwa pengaruh pembelajaran online terhadap hasil belajar siswa membuat prestasinya menjadi menurun karena materi menjadi sulit dipahami. Selama pandemi berlangsung, baik guru maupun siswa dituntut untuk melakukan pembelajaran dalam bentuk online. Seperti yang telah disebutkan di atas bahwasannya guru tidak setuju jika pemberian materi pelajaran biologi dilakukan dalam bentuk online. Sebagian besar guru berpendapat akan dampak yang dihasilkan jika pembelajaran terus menerus dilakukan secara daring, diantaranya pemahaman siswa dalam belajar menjadi tidak maksimal.

Kebebasan kepada guru untuk menjalankan tugasnya yaitu memberikan materi kepada siswa dengan menggunakan teknologi E-learning di MAN 2 Jember dirasa cukup efektif dilakukan dan dapat digunakan kesempatan agar menjadikan siswa lebih semangat dalam belajar. Cara guru dalam memanfaatkan faktor pendukung dalam pembelajaran daring adalah memaksimalkan penggunaannya dengan cara mencari media pembelajaran berupa video serta terus mengikuti perkembangan atau kemajuan peserta didik dalam mengikuti pembelajaran daring yang dilaporkan oleh orang tua melalui grup Whatsapp. Selain itu guru juga memberikan informasi atau hal-hal yang ditanyakan oleh peserta didik dalam pembelajaran (Putria, 2020).

Menurut Purwanto dalam Putria, $d k k$ (2020) selain adanya faktor pendukung dalam pelaksanaan pembelajaran daring, terdapat juga beberapa faktor penghambat yang ada dalam pembelajaran daring. Hal ini terjadi karena pembelajaran daring merupakan sesuatu yang baru bagi guru. Dengan adanya metode pembelajaran jarak jauh membuat para guru perlu waktu untuk beradaptasi dan mereka menghadapi perubahan baru yang secara tidak langsung akan mempengaruhi kualitas hasil belajar.

Faktor penghambat tersebut diantaranya belum semua peserta didik memiliki handphone. Faktor yang selanjutnya adalah rasa malas pada peserta didik pada saat 
mengerjakan tugas, mekipun sudah didukung dengan fasilitas yang menunjang pembelajaran. Faktor yang selanjutnya adalah masih banyak orang tua yang bekerja sehingga tidak dapat sepenuhnya membimbing peserta didik dalam pembelajaran. Ada beberapa cara untuk mengatasi hambatan tersebut, diantaranya adalah memberikan informasi diawal sebelum pembelajaran dilaksanakan agar pada saat pembelajaran semuanya sudah siap mengikuti pembelajaran. Selanjutnya adalah melakukan kerjasama dengan komite kelas terkait peserta didik yang belum memiliki handphone untuk dapat menanyakan kepada teman yang jarak rumahnya dekat agar dapat sama-sama mengikuti pembelajaran. Selain itu untuk orang tua yang sibuk bekerja guru memberikan kelonggaran dalam pengumpulan tugas (Putria, 2020).

\section{KESIMPULAN DAN SARAN}

\section{Kesimpulan}

Proses pembelajaran daring yang telah dilakukan dengan menggunakan teknologi informasi dan komunikasi di tengah pandemi COVID-19 telah memberikan dampak positif dan negatif terhadap hasil belajar siswa pada mata pelajaran biologi di lembaga pendidikan MAN 2 Jember. Salah satu dampak positifnya adalah siswa-siswi tersebut mendapatkan pengetahuan baru berupa penerapan teknologi informasi dan komunikasi dalam pembelajaran daring. Sedangkan dampak negatifnya adalah kebanyakan siswa-siswi tersebut masih kurang pemahaman mengenai penyampaian materi yang diberikan oleh guru melalui berbagai teknologi yang telah diajarkan, sehingga semangat belajar dan prestasi kebanyakan siswasiswi tersebut menurun. Penelitian ini telah memberikan hasil bahwa mata pelajaran biologi pada masing-masing tingkatan kelas di MAN 2 Jember menunjukkan ketidak efektifan pembelajaran baik pada siswa maupun guru.

\section{Saran}

Pentingnya penguasaan penggunaan teknologi informasi dan komunikasi merupakan hal yang harus dipelajari dan dipahami baik dari siswa dan guru agar mudah dalam mengaplikasikan pembelajaran daring di sekolah. Kemudian, hal yang terpenting yaitu pemahaman materi jika siswa paham dengan materi yang disampaikan maka prestasi akan meningkat, maka dari itu diharapkan para guru untuk lebih berusaha menerapkan metode yang lebih efektif lagi dalam menggunakan teknologi informasi dan komunikasi agar siswa mendapatkan hasil belajar yang maksimal. 


\section{DAFTAR RUJUKAN}

Adise, Ahmad Gawdy Prananosa. "Penggunaan Teknologi Informasi Dan Komunikasi Dalam Sistem Manajemen Pembelajaran Pada Masa Pandemi COVID-19." ALIGNMENT: Journal of Administration and Educational Management 3, no. 1 (2020).

Fauziyah, Nureza. "Dampak COVID-19 Terhadap Efektifitas Pembelajaran Daring Pendidikan Islam.” Jurnal Al-Mau'izoh 2, no. 2 (2020).

Jamaludin, Dindin. 2020. "Pembelajaran Daring Masa Pandemik COVID-19 Pada Calon Guru: Hambatan, Solusi Dan Proyeksi”. Karya Tulis Ilmiah, Lembaga Penelitian dan Pengabdian Kepada Masyarakat UIN Sunan Gunung Djati Bandung.

Hikmat, H., dkk. 2020. Efektivitas pembelajaran online selama masa pandemi COVID-19: Sebuah survey online. LP2M

Latip, Abdul. "Komunikasi Pada Pembelajaran Jarak Jauh Di Masa Pandemi COVID-19." Jurnal Edukasi Dan Teknologi 1, no. 2 (2020), 108-109.

Mahardika Arfi Esa. 2013. Analisis Hambatan Proses Pembelajaran Biologi Dan Cara Pemecahannya Dalam Pelaksanaan Ktsp Bagi Guru Kelas X Sma Di Kabupaten Sragen. Skripsi. Universitas Negeri Semarang

Mustakim. "Efektivitas Pembelajaran Daring Menggunakan Media Online Selama Pandemi COVID-19 Pada Mata Pelajaran Matematika.” Al - Asma Jurnal of Islamic Education 2, no. 1, (2020).

Novia, dkk. "Gambaran Kebutuhan Pembelajaran Daring PKBM Budi Utama Surabaya Pada Masa Pandemi COVID-19.” Jurnal Pendidikan Nonformal 5, no. 2, (2020).

Pangondian, Andrianto, dkk. 2019. Faktor - Faktor Yang Mempengaruhi Kesuksesan Pembelajaran Daring Dalam Revolusi Industri 4.0. Seminar Nasional Teknologi Komputer \& Sains (SAINTEKS). Universitas Gadjah Mada, Yogyakarta

Pawicara, Ruci \& Conilie, Maharani. “Analisis Pembelajaran Daring Terhadap Kejenuhan Belajar Mahasiswa Tadris Biologi IAIN Jember di Tengah Pandemi COVID-19.” Alveoli : Jurnal Pendidikan Biologi 1, no. 1, (2020).

Putria, $d k k$. "Analisis Proses Pembelajaran Dalam Jaringan (DARING) Masa Pandemi COVID-19 Pada Guru Sekolah Dasar.” Jurnal Basicedu 4, no. 4, (2020).

Simatupang, $d k k$. "Efektivitas Pelaksanaan Pengajaran Online Pada Masa Pandemi COVID19 dengan Metode Survey Sederhana.” Prodi Pendidikan Kimia Universitas Kristen Indonesia, Jakarta 13, no 2, (2020). 